\title{
Biodiversity, conservation and current threats to European honeybees*
}

\author{
Pilar DE LA RÚA ${ }^{1 * *}$, Rodolfo JAFFÉ ${ }^{2 * *}$, Raffaele DALL'OLIO ${ }^{3 * *}$, Irene MUÑOZ ${ }^{1}$, \\ José SERRANO ${ }^{1}$ \\ ${ }^{1}$ Dpto. de Zoologia y Antropología Física, Facultad de Veterinaria, \\ Universidad de Murcia, 30100 Murcia, Spain \\ ${ }^{2}$ Institut für Biologie, Martin-Luther-Universität Halle-Wittenberg, Hoher Weg 4, 06099 Halle (Saale), Germany \\ ${ }^{3}$ CRA-API, Via di Saliceto 80, 40128 Bologna, Italy
}

Received 12 August 2008 - Revised 20 January 2009 - Accepted 12 February 2009

\begin{abstract}
Europe harbours several endemic honeybee (Apis mellifera) subspecies. Yet the distribution of these subspecies is nowadays also much influenced by beekeeping activities. Large scale migratory beekeeping and trade in queens, coupled with the promiscuous mating system of honeybees, have exposed native European honeybees to increasing introgressive hybridization with managed non-native subspecies, which may lead to the loss of valuable combinations of traits shaped by natural selection. Other threats to European honeybees are factors that have caused a progressive decline in A. mellifera throughout the world in recent years, leading to large economic losses and jeopardizing ecosystem functioning. We review the biodiversity of European honeybees and summarize the management and conservation strategies employed by different countries. A comprehensive picture of the beekeeping industry in Europe is also provided. Finally we evaluate the potential threats affecting the biodiversity of European honeybee populations and provide some perspectives for future research.
\end{abstract}

Apis mellifera / subspecies / biogeography / conservation / Europe / beekeeping

\section{OVERVIEW OF THE EVOLUTIONARY BRANCHES AND MOLECULAR LINEAGES OF APIS MELLIFERA}

\subsection{Description}

Honeybee (Apis mellifera L.) populations show considerable differences in morphological, behavioural and population biological characters across their vast natural range from southern Africa to northern Europe as a result of historical patterns of isolation and adaptation to particular habitats. Many of these bio-

Corresponding author: P. De la Rúa, pdelarua@um.es

* Manuscript editor: Robert Paxton

** These authors have contributed equally to this review. logically distinct populations have been recognised as subspecies (Adam, 1983; Ruttner, $1988,1992)$ that have been clustered into three main groups or branches by morphometric methods (Box 1) and that are each geographically restricted in distribution to: the Near East (O branch), Tropical Africa (A branch) or the Mediterranean/Europe (M and C branches) (Ruttner, 1988). It is this latter group ( $\mathrm{M}$ and $\mathrm{C}$ branches) that is predominantly present in Europe, composed of West Mediterranean and North European 'M-subspecies' (A. m. iberiensis and A. $m$. mellifera) and Central and Southeast European 'C-subspecies' such as A. m. ligustica, A. m. cecropia, A. m. macedonica and A. m. carnica (Fig. 1).

With the availability of new molecular tools (Boxes 2 and 3) these branches have been 


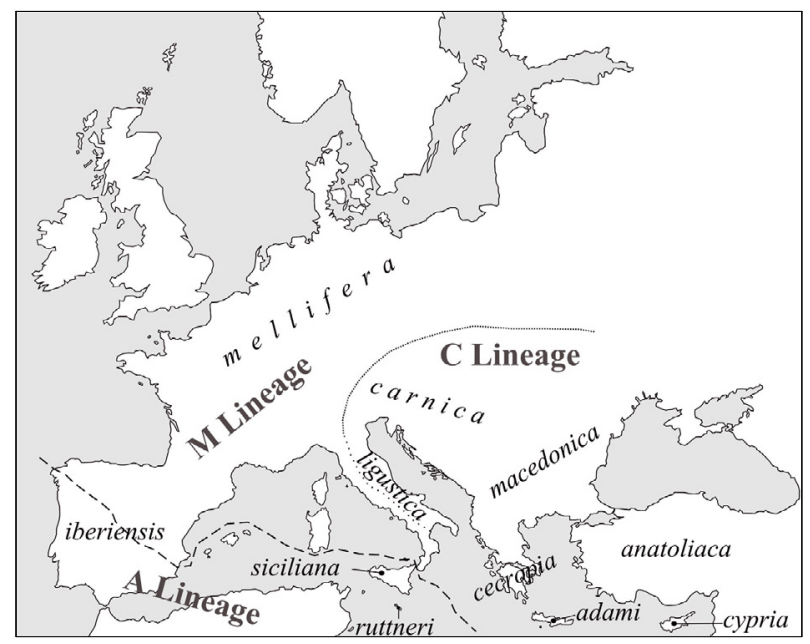

Figure 1. Approximate natural distribution of the Apis mellifera evolutionary lineages and subspecies in Europe.

confirmed as evolutionary lineages, with slight modifications; subspecies such as $A$. m. intermissa and A. m. sahariensis are now included in the African A lineage (Cornuet and Garnery, 1991), and the subspecies A. m. anatoliaca and A. $m$. caucasica that were originally grouped in the oriental 'O-branch', together with $A$. m. meda, A. m. syriaca, A. m. adami, A. m. cypria and A. m. armeniaca, have now been included in the evolutionary C lineage (Smith et al., 1997; Franck et al., 2000b). Still some controversy exists in this grouping of subspecies to evolutionary lineages. For example, A. m. cypria from Cyprus has been recently grouped into the $\mathrm{O}$ branch based on morphology, and into the $\mathrm{C}$ lineage based on molecular markers (Kandemir et al., 2006).

\subsection{Evolutionary lineages and subspecies distribution in Europe}

The evolutionary lineages are restricted in distribution across Europe and therefore exposed to diverse climates and habitats, but are nowadays also confronted by a range of anthropogenic influences (Moritz et al., 2005). The natural distribution of the $\mathrm{M}$ evolutionary lineage spans Western Europe whereas the C lineage occupies Eastern Europe. The African
A evolutionary lineage is found in populations from a limited number of Mediterranean islands and also in the south-western part of the Iberian Peninsula (Fig. 1). The present distribution of European honeybee subspecies has also been influenced by their location just after the Last Glacial Maximum (LGM), when the mountain chains of the Pyrenees, the Alps and the Balkans acted as geographic barriers in maintaining the isolation of populations (Ruttner, 1988).

The subspecies with the largest natural area of distribution is A. m. mellifera, the common European "black bee", which extends from France to Scandinavia and from the British Isles, where they have been present for at least the last 4000 years (Carreck, 2008), to Poland and the Ukraine, and where it readily hybridizes with subspecies of the $\mathrm{C}$ and $\mathrm{O}$ morphological branches (Meixner et al., 2007). Nowadays this subspecies also hybridizes with neighbouring subspecies such as $A$. $m$. ligustica from Italy and A. m. carnica from Balkan countries in their natural contact zones, but also through human mediated introductions by professional and amateur beekeepers (Garnery et al., 1998a, b; Jensen et al., 2005).

The Iberian honeybee A. m. iberiensis is distributed in Spain, Portugal and the Balearic Islands (Radloff et al., 2001). This subspecies 
has been the subject of numerous studies due to its hybrid status as a result of secondary contact between A. m. intermissa and A. m. mellifera (Cánovas et al., 2008 and references herein). This subspecies differs from the black bee in certain characters (Ruttner, 1988) probably because of the geographic barrier of the Pyrenees (Miguel et al., 2007).

The natural distribution of the Italian honeybee A. m. ligustica or "yellow bee" is the Italian Peninsula, as it is confined by the Alps to the North and the Mediterranean Sea southwards. Its hybrid origin, derived from A. $m$. mellifera and A. m. carnica, has been well supported by molecular markers (Franck et al., 2000a).

The "Carniolan bee" $A$. $m$. carnica is distributed across central-eastern European countries such as Austria, Slovenia, Croatia, Bosnia-Herzegovina, Albania, Serbia, Hungary and Romania. Local morphometric varieties within this subspecies, resembling ecotypes, have been described according to zoogeographic zones: Alpine, Pannonic and Pontic from west to east (Ruttner, 1988). These ecotypes are influenced by neighbouring subspecies: A. m. ligustica to the west and along the Adriatic coast, A. m. mellifera to the N/NW and $A$. m. macedonica to the S/SE (Muñoz et al., unpubl. data).

A. m. macedonica extends across Bulgaria, Greece, Romania, Ukraine and Turkey. Its differentiation from other Greek honeybees is supported by morphological and mitochondrial DNA data (Bouga et al., 2005b) but not so clearly by nuclear allozymes (Bouga et al., 2005a).

A. m. cecropia is distributed all over southern Greece, including the Peloponnese. Despite the morphological differences between this subspecies, A. m. adami and A. m. cypria, no significant differentiation has been observed between them in mitochondrial and allozyme data (Bouga et al., 2005a, b).

According to Ruttner (1988), four subspecies occur in Turkey: A. m. caucasica, in the extreme northeast of Anatolia along the eastern Black Sea coast, $A$. m. meda, found in the southeast and $A$. $m$. syriaca, in the extreme south close to Syrian border. A. m. anatoliaca occurs throughout the rest of Turkey, including Thrace.

Mediterranean islands are basically characterized by mild, rainy winters and hot, dry summers. But isolation has led to at least four of them harbouring their own honeybee subspecies: A. m. siciliana on Sicily, A. m. ruttneri on Malta, A. m. cypria on Cyprus and A. m. adami on Crete. These subspecies have different mainland origins. An African origin has been shown for the honeybee populations on Sicily (Arias and Sheppard, 1996; Garnery et al., 1993; Sinacori et al., 1998) and Malta (Sheppard et al., 1997). Cypriot honeybees show an European origin based on mitochondrial markers, but from the morphological point of view they belong to the Near East O branch (Kandemir et al., 2006; Bouga et al., 2005b), and the Cretan honeybee is also included in the Near East $\mathrm{O}$ branch, based on morphology.

\subsection{Zones of natural hybridization}

New molecular markers, namely singlenucleotide polymorphisms (SNPs), have supported an African origin of A. mellifera (Whitfield et al., 2006). From Africa at least two and possibly three subsequent expansions took place into Eurasia: to Western Europe the $\mathrm{M}$ lineage, to Eastern Europe the $\mathrm{C}$ lineage and to Asia the $\mathrm{O}$ lineage. These lineages were restricted to the main Mediterranean refugia during the LGM, and from there two of the main European races moved northwards: A. $m$. mellifera from the Iberian Peninsula (Franck et al., 2000a) and A. m. carnica from the Balkan Peninsula (Ruttner, 1988). This successful colonisation of northern regions of Europe was achieved by the ability of honey bees to survive several months of cold winter when they are confined to the nest, without any flight activity.

The northward migration of $A . m$. mellifera from the Iberian Peninsula was followed by the expansion of the north-African A. m. intermissa into South Iberia. This secondary contact gave rise to the subspecies A. m. iberiensis. The present Iberian honeybee populations reflect both natural and human influences, 
such as extensive migratory seasonal movements of colonies by beekeepers (De la Rúa et al., 2002a, 2005; Cánovas et al., unpubl. data).

Franck et al. (2000a) hypothesized that Italy was invaded by honeybee populations from neighbouring France and Slovenia: a preliminary invasion of $A$. m. mellifera along the Ligurian coast was followed by the expansion of A. m. carnica along the Adriatic coast. This hybridization is ancient and could have occurred at any time during the Riss period (120000 years B. P.). Subsequently, the Italian honeybee A. m. ligustica was restricted to the Italian Peninsula but could not expand into other parts of Europe during the postPleistocenic warm period due to the geographical barrier of the Alps.

The Balkan races A. $m$. carnica, A. m. macedonica and A. m. cecropia (from north to south) make up a closely related group of populations, as shown by recent molecular analyses of Carniolan honeybee populations from Serbia, Slovenia and Croatia (Sušnik et al., 2004; Kozmus et al., 2007), and A. m. macedonica (Muñoz et al., unpubl. data), which suggest that a fair amount of gene flow exists between them. A hybrid origin has also been suggested for other subspecies such as A. m. meda (Arias and Sheppard, 1996), which should be further investigated.

\section{INTROGRESSION IN HONEYBEE POPULATIONS}

The mating system of the honeybee is considered to lead to one of the most extreme forms of panmixia in the animal kingdom, because it is based on the aggregation of thousands of males from many colonies at drone congregation areas (DCAs), which virgin queens visit in order to mate repeatedly with tens of drones (Baudry et al., 1998; Koeniger and Koeniger, 2000; Jaffé et al., 2009). Controlling queen mating is extremely difficult (Neumann et al., 1999a, b). Although instrumental insemination provides complete control over mating, the expensive instruments involved and the necessary highly skilled and time-consuming techniques dis- courage most private beekeepers from practicing it (Lodesani and Costa, 2003). Gene flow between neighbouring honeybee subspecies is therefore common (Jensen et al., 2005). Introgression and displacement can proceed extremely fast, as shown by the rapid spread of Africanized honeybees through the New World (Schneider et al., 2004). Consequently, human-driven introductions of foreign honeybee subspecies into habitats already occupied by native honeybees may result in immediate hybridization between them.

Since the beginnings of apiculture the western honeybee has been spread worldwide for exploitation as a honey producer and crop pollinator (Moritz et al., 2005). During the last centuries, A. mellifera was introduced in places that lacked native honeybee populations, such as the New World (Freitas et al., 2009), Asia (Oldroyd and Nanork, 2009) and Australia (Batley and Hogendoorn, 2009). Likewise, particularly docile and honey-productive "superior" subspecies have been disseminated outside their natural range, into areas where other subspecies are native or were already introduced.

The Italian honeybee (A. m. ligustica) is among the favourite subspecies kept by many beekeepers around the world (Ruttner, 1988). Intensive breeding of queens for exportation resulted in the introduction of Italian honeybees in northern Europe, the New World, Australia and the Canary Islands, among other places (Franck et al., 2000a; De la Rúa et al., 2001a). Likewise Carniolan bees (A. m. carnica) have attracted the attention of many beekeepers worldwide. Moreover, the small Carinthian hives, traditionally employed by beekeepers in the Austrian-Slovenian border, facilitated the transport of A. m. carnica bees outside their natural range. Already in the 18th century the Carniolan bee was well known all over Europe (Ruttner, 1988). Also included among the preferred subspecies is the Caucasian honeybee (A. $m$. caucasica), which has been intensively used by beekeepers for more than 100 years (Ruttner, 1988). The natural range of Caucasian honeybees has been artificially expanded from the Caucasus to Western Turkey and Bulgaria (Ivanova et al., 2007), while a significant number of hives have been 
introduced into Russia, Ukraine, Germany and France (Ruttner, 1988).

The intense dissemination of Italian and Carniolan honeybees throughout the European continent has resulted in the almost complete replacement of A. m. mellifera by A. m. carnica in central European countries such as Germany, and the hybridization of all three subspecies in Scandinavian countries and the British Isles (Jensen et al., 2005). Moreover, after finding little population differentiation in continental Italy, Dall'Olio et al. (2007) concluded that intensive queen breeding and migratory beekeeping have caused an amalgamation of local Italian Peninsula populations into a single Italian gene pool.

Eastern Europe has also been subject to the introduction of foreign honeybee subspecies. In Bulgaria, A. m. ligustica, A. m. carnica and A. m. caucasica have been regularly reared for more than three decades, strongly hybridizing with the native A. m. macedonica (Ivanova et al., 2007). By analyzing allozyme variation at 12 loci across honeybee populations of Greece and Cyprus, Bouga et al. (2005a) found that Cyprus and the Island of Kasos are the only reservoirs of relatively pure native Greek honeybee populations; in central Greece, commercial queen breeding and migratory beekeeping have contributed to the almost complete hybridization of the four native subspecies originally described by Ruttner (1988): A. m. cecropia, A. m. macedonica, A. m. adami, and A. m. carnica. Furthermore, the already heterogeneous honeybee populations of continental Greece have suffered introgression from other introduced subspecies (A. m. ligustica, Buckfast hybrids and presumably A. m. caucasica) (Bouga, pers. com.). Intensive queen breeding and migratory beekeeping over long distances have also caused the hybridization of Turkish subspecies (Ruttner, 1988; Kence, pers. com.).

Native honeybee populations inhabiting Mediterranean Islands have similarly suffered introgression from foreign honeybee subspecies. Among the Balearic Islands (Spain), only Mallorca seems to harbour a relatively well preserved honeybee population, whereas Formentera, Ibiza and Menorca show evidence of recent introgression events that have sub- stantially changed the genetic pool of the ancestral local populations (De la Rúa et al., 2001b, 2003). Moreover, most native honeybees from Fomentera are likely to have disappeared due to a combination of the effects of diseases and low population size. Similarly, Frank et al. (2000a) showed that the exportation of Italian queens to Sardinia resulted in the nearly complete replacement of native M4 mitotypes by Italian $\mathrm{C} 1$ mitotypes. Although Sicilian populations only displayed ancestral African mitotypes, some introgression from neighbouring $A$. $m$. ligustica populations has also been found (Frank et al., 2000a).

\section{MANAGEMENT AND CONSERVATION}

The conservation of native European honeybees should be a pressing priority given that: (1) Native subspecies are important reservoirs of local adaptations (ecotypes), ultimately determining the survival and pollination success of honeybees in the wild (Randi, 2008). Their extinction thus implies the loss of a valuable combination of traits shaped by natural selection over extended periods of time. (2) Honeybees are key generalist pollinators, with large perennial colonies that ensure high local pollination throughout the flowering season. For instance, pollination services provided by honeybees have been valued in many billions of dollars (Kevan and Phillips, 2001; Southwick and Southwick, 1992). (3) Because of their outstanding pollination efficiency and their ability to compensate for a decline in visits by native pollinators in fragmented habitats, honeybees have been regarded as "rescue pollinators" (Aizen and Feinsinger, 1994; Dick, 2001). (4) European honeybees are the core of a thriving commercial business which, as for many other similar industries, is likely to run unsustainably in the near future (van Engelsdorp et al., 2007; 2nd COLOSS conference, Athens 2008 unpubl. data).

Any realistic honeybee conservation effort must take into consideration the current status of managed honeybee populations across Europe. Therefore, detailed beekeeping information of each country needs to be gathered 
prior to designing future conservation programmes. In an attempt to survey the different beekeeping practices across the continent, we consulted research institutions, beekeeping organizations, published reports and open access data bases, gathering beekeeping statistics on 33 European countries (Appendix I in supplementary data). It must be pointed out, however, that the accuracy of these estimates is questionable. While highly organized and dynamic beekeeping organizations constantly update national beekeeping statistics in some countries, there is a lack of, or only outdated, information for others. For instance, annual censuses of the total number of hives in each EU country were taken from 1998 to 2008. Given that the number of beekeepers and the number of managed hives have suffered a decline during the past decades (2nd COLOSS conference, Athens 2008), the older estimates are likely to overestimate the current number of hives. Moreover, the national number of managed hives is usually obtained from professional beekeepers, which excludes those managed by amateurs. Nevertheless, assuming all estimates may suffer similar biases, they can still be used to make between-country comparisons. The European Commission granted 23 million euros to apicultural activities in 2005 (Council Regulation EC-N ${ }^{\circ} 797 / 2004$ ), after estimating a total of 11.5 million hives in the Community (EC, 2004, p. 17). The 24 EU member states at 2005 (of a total of $27 \mathrm{EU}$ states) from which we were able to obtain any data held 11594735 hives, which fairly resembles the European Commission figure.

The density of managed hives is an informative indicator of a nation's beekeeping status. Moreover, since wild honeybee populations have all but disappeared in many European countries (Moritz et al., 2007a; Jaffé et al., unpubl. data), the density of managed hives may actually reflect the actual size of honeybee populations in some areas of the continent. Based on our surveyed data, we calculated an average density of managed hives in Europe of $4.04 \pm 2.82$ colonies per $\mathrm{km}^{2}$. Looking at the density of managed hives through the continent, two main patterns become evident: beehives become more abundant from North to South and from West to East (Fig. 2).
A recent study to measure the density of feral/wild honeybee populations across $\mathrm{Eu}-$ rope and Africa also found lower densities at higher latitudes (Jaffé et al., unpubl. data). Beekeeping operations in the Mediterranean region are thus likely to benefit from milder climates, allowing the maintenance of a higher density of hives. In contrast, the West-East increase in the density of managed hives cannot be explained by climatic factors alone. Countries such as Germany and Hungary share a similar continental climate, and yet beehive densities in Hungary are more than five times higher than in Germany (Fig. 2). In contrast, the number of beekeepers is five times higher in Germany than in Hungary (Appendix I in supplementary material), and in consequence Hungarian beekeepers handle on average 57 more hives than do German beekeepers. Beekeepers of both countries keep almost exclusively Carniolan bees, and therefore differences in beekeeping practices more likely explain the abundance of managed hives. For instance, the density of managed hives across 33 European countries was positively correlated to the mean number of hives kept by local beekeepers (Spearman rank correlation $\left.\mathrm{R}=0.57 ; t_{33,2}=3.82 ; P<0.001\right)$, suggesting the size of beekeeping operations influences the local abundance of beehives. We nevertheless cannot establish an unambiguous causal relationship between these two variables.

Another interesting pattern observed in Figure 2 is the political, rather than geographic, distribution of beehive densities. Major differences in hive densities (more than 4 hives $/ \mathrm{km}^{2}$ ) occur between neighbouring countries such as Germany and the Czech Republic, Italy and Slovenia, Albania and Greece, and Hungary and nearly all its surrounding countries. Again, this highlights the impact of different beekeeping policies on the abundance of beehives. For instance, if beekeeping policies are able to change the genetic composition of a honeybee population (see above), they certainly seem capable of influencing its size.

The success of future honeybee conservation efforts will therefore depend on the ability to coordinate the implementation of large scale beekeeping policies oriented at preserving native honeybee subspecies. A first necessary 


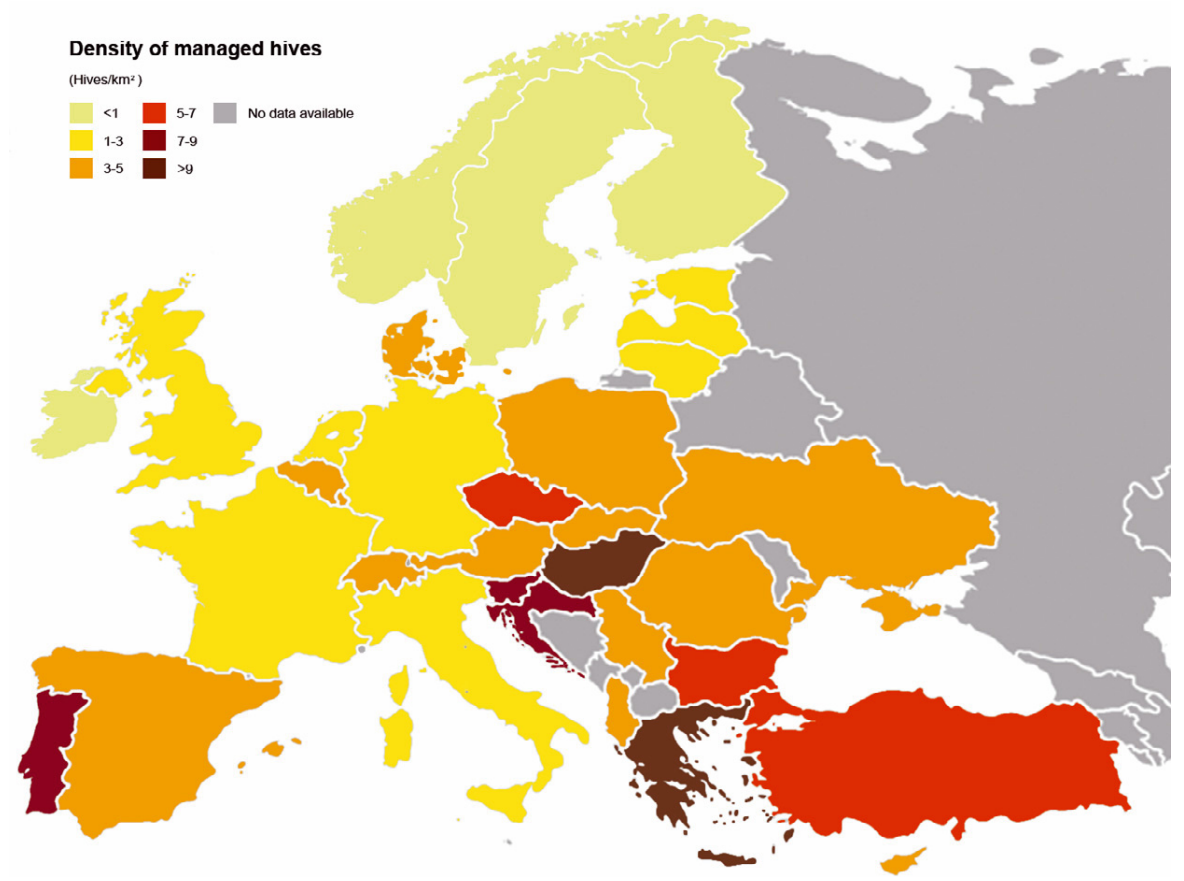

Figure 2. Density of managed hives in 33 European countries (based on Appendix I in supplementary data).

step is thus facilitating information flow by making available the beekeeping statistics of each country to conservation policy makers. Large scale beekeeping surveys (Lodesani and Costa, 2003; EFSA, 2008) and the creation of open access data bases (such as APISERVICES, available at www.beekeeping.com/ countries/) are worthy initiatives enhancing information flow. We then suggest two main courses of action to be followed by future protection policies: restricting the introduction of "superior" subspecies into habitats already occupied by native honeybees, and maintaining the genetic diversity of native honeybee populations.

\subsection{Restricting the introduction of "superior" subspecies into habitats already occupied by native honeybees}

The introduction of foreign subspecies into habitats already occupied by native honeybees not only exposes the native populations to for- eign pathogens but also to introgressive hybridization (Matheson et al., 1996). Exposure to foreign pathogens can have catastrophic consequences, as demonstrated by the drastic decline of feral US bee populations after the introduction of Varroa destructor mites in the 1980's to North America (Kraus and Page, 1995). Introgressive hybridization, on the other hand, modifies the genetic pool of local honeybee populations, leading to the loss of their genetic identity. With unique behavioural and morphological traits, native subspecies constitute important reservoirs of local adaptations, ultimately determining the survival of honeybees in natural habitats (Randi, 2008).

Many native subspecies and ecotypes have been exposed to introgressive hybridization with introduced Italian, Carniolan and Caucasian bees (Franck et al., 2000a; De la Rúa et al., 1998, 2001a, b, 2003; Jensen et al., 2005; Ivanova et al., 2007). Future honeybee conservation efforts should therefore aim at reducing the introduction of these subspecies into areas already occupied by other native 
honeybees. This will not be an easy task, considering breeding and importation of these subspecies have become traditional practices, long established in many countries outside their natural range (Ruttner, 1988). Moreover, economic incentives may prevent beekeepers from employing less productive (and less gentle) but native honeybee subspecies. A possible alternative could therefore be to reward conservation efforts, either by giving a higher value to bee products coming from native subspecies, or by subsidizing production costs of beekeepers employing native honeybees. For instance, the current European regulation on organic beekeeping (Council Regulation EC$\mathrm{N}^{\circ} 1804 / 1999$ ) states that "preference shall be given to the use of European breeds of Apis mellifera and their local ecotypes". Making this clause compulsory could be a first step towards the legal protection of native honeybees in Europe.

\subsection{Maintaining the genetic diversity of native honeybee populations}

Beekeeping policies can profoundly influence the genetic diversity of honeybee populations (Estoup et al., 1995; Franck et al., 2000a; Jensen et al., 2005). Whilst the importation of foreign queens can result in introgressive hybridization of native subspecies, large scale queen breeding and the widespread propagation of selected stock will ultimately reduce the effective population size, making populations more susceptible to the deleterious effects associated with inbreeding (reviewed in Zayed, 2009). On the other hand, the regular movement of hives, aiming at increasing and diversifying honey production (migratory beekeeping), could artificially increase population genetic diversity (Estoup et al., 1995). Honeybee populations in countries with the highest densities of managed hives (more than 5 hives $/ \mathrm{km}^{2}$ ), such as Portugal, the Czech Republic, Hungary, Slovenia, Croatia, Greece, Bulgaria and Turkey (Fig. 2), are likely to be strongly affected by national beekeeping policies. These countries should therefore be particularly cautious when designing and implementing protective policies.
At least four subspecies can still be distinguished in Turkey (A. m. anatoliaca, A. m. caucasica, A. m. meda, and A. m. syriaca), showing a high genetic diversity (Kandemir et al., 2000; Bodur et al., 2007). However, intensive queen breeding and migratory beekeeping will homogenize the gene pool of Turkish bee populations (Kence, unpubl. data), as has already occurred in Greece (Bouga et al., 2005b). Regulating migratory beekeeping in Turkey to allow hives or queens to be moved within, but not between, the distributional ranges of different native subspecies could reduce hybridization and help to preserve them. Likewise, national parks and other protected areas, because of their valuable biota, might be selected to conserve native honeybees from homogenising practices.

In Northern-Central Europe, where Carniolan bees have become the dominant subspecies as a result of beekeeping practices that have displaced the native black bees, preserving the genetic diversity of these long-established populations seems the most worthy conservation approach. Indigenous non-hybridized $A$. $m$. carnica populations still exist in Slovenia, Croatia and Serbia (Sušnik et al., 2004; Kozmus et al., 2007; Muñoz et al., unpubl. data), constituting an important genetic resource for future bee breeding programmes. Relatively pure populations of $A$. m. mellifera nevertheless still exist across the region, ranging from Spain to Norway (Jensen et al., 2005), and constituting a valuable gene pool for controlled breeding programmes selecting for favourable traits such as resistance against honeybee diseases. Miguel et al. (2007) concluded that all northern European honeybees (M lineage) seem to have originated from an ancestral population of the Iberian Peninsula that dispersed north after the LGM. The area between the Iberian Mountain Range in central Spain and the Pyrenees was found to contain a particularly valuable genetic reservoir for $\mathrm{M}$ mitotypes in Western Europe (De la Rúa et al., 2004). Although its preservation is tightly linked to the adequate management of the whole environment, regional authorities must be aware of these findings to prevent implementation 
of undesirable policies that directly threaten these honeybee populations.

Similarly, the preservation of Mediterranean islands' endemic honeybee subspecies would ensure a rich source of genetic material for future breeding programmes. Given their natural isolation this should theoretically be an easy task, and will basically depend on the ability of beekeeping policies to restrict the introduction of foreign honeybees (De la Rúa et al., 2001b, 2003; Bouga et al., 2005b).

\subsection{Present conservation programs}

Several honeybee conservation programmes have been undertaken in Europe. One of the best documented is that performed by the Danish Beekeepers' Association and the Læsø Beekeepers' Association on behalf of the Danish Government since 1993 and the European Union since 1998 (Jensen and Pedersen, 2005). The small Danish island of Læs $\varnothing$, located between Sweden and the Danish peninsula, harbours the last survivors of the Danish brown honeybee A. m. mellifera. This honeybee population was firstly characterized by morphometry (analysis of the cubital index and colour) in 1986, resulting in $97.4 \%$ of the examined bees showing values characteristic of $A$. m. mellifera. This percentage decreased in a 1990 study, indicating that hybridization was increasing. Lately, genetic markers confirmed the distinctiveness of the Læs $\varnothing$ population that, together with its high genetic variation, prompted a proper breeding scheme. Controversy arose as not all the beekeepers on the island agreed to breed A. $m$. mellifera but rather preferred the Italian yellow honeybee $A . m$. ligustica, despite the fact that the latter was banned by national Danish laws and a decision of the Court of Justice of the European Union. In 1998 an appeal and judgment gave support to the Danish government to protect and preserve the subspecies A. $m$. mellifera on Læs $\varnothing$ and to prohibit beekeeping with other subspecies. A genetic survey in 2003 across the island demonstrated that only $35 \%$ of a reduced sample could be identified as A. m. mellifera, whereas $55 \%$ were considered as hybrids and $10 \%$ were A. $m$. ligustica (Jensen et al., 2005).
On the Canary Island of La Palma, due to the interest of the local beekeeping association and the Canary Government, a programme of selection and preservation of the local black honeybee was initiated in 1996. Its first goal was to characterize the insular honeybee populations through molecular data. De la Rúa et al. (1998, 2001a) first characterized the Canary honeybee populations, finding particular mitochondrial haplotypes that were later confirmed as belonging to an Atlantic evolutionary sublineage, also spread in other Macaronesian archipelagos such as the Azores and Madeira (De la Rúa et al., 2006). Although the island population was free of $V$. destructor until 2005, losses of about the $50 \%$ of the local honeybee populations are predicted nowadays due to this parasitic mite. Regional laws established special measures to control the conservation, recuperation and selection of the Canary black honeybee in 2001. Among other activities, a natural mating area favoured by the particular topography of the island was established that allows its saturation with local drones, and local honeybee queens are distributed among beekeepers.

In addition to honeybee conservation efforts on islands, other strategies are taking place in Europe. In France one of the country's four identified ecotypes of A. m. mellifera occurs in the Landes region (Louveaux et al., 1966), characterized by an unusual brood cycle adapted to the late season blooming of ling heather, Calluna vulgaris. This brood cycle was found in almost $50 \%$ of the colonies analyzed by Strange et al. (2007) and, therefore, several morphological and molecular approaches have been used to distinguish this ecotype from introduced Buckfast hybrids (Strange et al., 2008). Unfortunately no single diagnostic morphological or molecular marker was able to distinguish the Landes ecotype, but the combined data provided a powerful suite of characters for its identification. For conservation efforts it was concluded that the potential breeder stock should be screened by using behaviour, morphology and molecular tools to prevent breeding from introgressed stock.

Other countries such as Norway, Slovenia and Austria are beginning to establish protected conservation areas for their 
Table I. Summary of the current threats to European honeybees.

\begin{tabular}{|c|c|c|}
\hline Threat & Effect & Repercusion on honeybees \\
\hline \multirow[t]{2}{*}{ Pollution } & $\begin{array}{l}\text { Water and soil contam- } \\
\text { ination }\end{array}$ & $\begin{array}{l}\text { Pesticides (spray, coated seeds); neonicotinoids; herbicides } \\
\text { may be accumulated by honeybees }\end{array}$ \\
\hline & Global warming & $\begin{array}{l}\text { Changed blooming season related to climate changes may } \\
\text { limit colony growth }\end{array}$ \\
\hline \multirow[t]{2}{*}{$\begin{array}{l}\text { Introduction of foreign } \\
\text { species }\end{array}$} & $\begin{array}{l}\text { Dissemination of for- } \\
\text { eign pathogens and par- } \\
\text { asites }\end{array}$ & $\begin{array}{l}\text { SHB (Aethina tumida), predators (Vespa velutina, Merops } \\
\text { apiaster); mites (Varroa destructor, Acarapis woodi, Tropi- } \\
\text { laelaps clarae); mycoses (Ascosphera apis, Aspergillus } \\
\text { sp., Nosema apis, Nosema ceranae); Senotainia tricuspis; } \\
\text { AFB (Paenibacillus larvae); EFB (Melissococcus pluto- } \\
\text { nius, Paenibacillus alvei, Streptococcus faecalis); proto- } \\
\text { zoa (Malpighamoeba melleficae), viruses (CPV, SBV, APV, } \\
\text { DWV) }\end{array}$ \\
\hline & $\begin{array}{l}\text { Dissemination of for- } \\
\text { eign subspecies }\end{array}$ & $\begin{array}{l}\text { Introgressive hybridization with native honeybee sub- } \\
\text { species }\end{array}$ \\
\hline Intensive land use & $\begin{array}{l}\text { Destruction of natural } \\
\text { habitats }\end{array}$ & Loss of suitable nesting and foraging habitats \\
\hline $\begin{array}{l}\text { Dissemination of ge- } \\
\text { netically modify crops }\end{array}$ & $\begin{array}{l}\text { Displacement of wild } \\
\text { flora }\end{array}$ & $\begin{array}{l}\text { Modification of natural habitats with the possible loss of } \\
\text { alternative floral resources suitable for honeybees. }\end{array}$ \\
\hline $\begin{array}{l}\text { Detrimental beekeep- } \\
\text { ing practices }\end{array}$ & $\begin{array}{l}\text { Migratory beekeeping } \\
\text { and queen trade over } \\
\text { long distances } \\
\text { Large scale selective } \\
\text { queen breeding }\end{array}$ & Hybridization of different subspecies \\
\hline $\begin{array}{l}\text { Loss of incentives for } \\
\text { beekeeping }\end{array}$ & $\begin{array}{l}\text { Reduced beekeeping } \\
\text { activity }\end{array}$ & $\begin{array}{l}\text { Reduction in European honeybee populations and possible } \\
\text { extinction of some subspecies }\end{array}$ \\
\hline $\begin{array}{l}\text { Lack of protective poli- } \\
\text { cies }\end{array}$ & $\begin{array}{l}\text { No control over bee- } \\
\text { keeping practices }\end{array}$ & All effects mentioned above \\
\hline
\end{tabular}

autochthonous subspecies (A. m. mellifera and A. $m$. carnica, respectively) where there is no known introduction of foreign subspecies, and to promote their legal protection. In Switzerland, pure-bred lines of A. m. mellifera are maintained as a conservation instrument to avoid gene flow from introduced A. m. carnica, but recent molecular analyses have revealed a high frequency of hybrids in most pure breeding populations, suggesting that the actual management approach should be adjusted to improve efficiency (SolandReckeweg et al., 2008).

As stated by Carreck (2008): 'management decisions need to be made on a case by case basis, and must be based on a sound understanding of the underlying biology of the ecosystems involved'. Therefore conservation efforts may need to vary across European countries characterized by different environmental conditions.

\section{CURRENT THREATS}

The economic value of honeybees as honey producers plays a minor role compared to their economic value as crop pollinators. The increased crop yield achieved by insects (mainly honeybees) has been calculated to be about $€ 1200$ per colony (in the EU25 economy, annually worth $€ 14.2 \times 10^{9}$, Gallai et al., 2009). In addition to crops, honeybees are thought to pollinate around $80 \%$ of wild flora. Consequently, honeybees are considered the fourth most important agricultural livestock sector in several European countries, one that is threatened by an increasing number of factors (Tab. I).

\subsection{Land use}

In most industrialized countries, intense land use has led to a progressive reduction of 
suitable habitats for honeybees, with a negative impact on feral and wild populations (Kremen et al., 2002; Biesmeijer et al., 2006; Flynn et al., 2009). Agricultural intensification and forestry have been shown to reduce the diversity and abundance of native bees in the US, diminishing their pollination services by 3 to 6-fold (Kremen et al., 2002). In Europe, the commonly practiced intense land use (extensive fields of a single annual crop or monoculture timber forests) is likely to reduce not only the availability of floral resources but also suitable nesting sites for honeybees (Biesmeijer et al., 2006; Murray et al., 2009).

In areas of intense land use, facilitating the establishment of native honeybees in nature reserves may be a strategy to reestablish wild populations. Many European governments (e.g. Belgium, Netherlands and the UK), however, have implemented national policies to warrant the legal exclusion of managed pollinators from Protected Areas (see sections 14 and 16 of the UK's Wildlife and Countryside Act 1981), based on questionable evidence on competition between honeybees and other native pollinators (reviewed by Huryn, 1997 and Paini, 2004). Based on the same evidence, other countries such as Germany and Austria permit apiculture within designated Protected Areas.

The impact of global environmental change has been recently reviewed, with evidence for correlated shifts at both phenotypic and genetic levels (Reusch and Wood, 2007), suggesting an overall biodiversity loss. Thus, in the decades to come, the environment and apiculture are expected to be highly influenced by the concurrent processes of global warming and changes in hydrological cycles. As the climate is predicted to change distinctly and differently in each geographic region, the effects of climate change on honeybee population dynamics may be specific to a location.

\subsection{Pathogens and parasites}

Huge colony losses have been reported worldwide in the last decade, with a peak in the last couple of years; many European countries such as Germany, Italy, Turkey, Switzerland, Poland, Slovenia and Croatia estimated more than 30\% colony losses in 2007 (2nd COLOSS conference, Athens 2008), resembling the worldwide trend. Even higher losses were recently reported in the US where socalled colony collapse disorder (CCD) resulted in the death of hundreds of thousands of colonies (van Engelsdorp et al., 2007). A combination of factors like the mite Varroa destructor, Varroa-associated viruses, Nosema microsporidia, drought, bacteria and/or fungi are assumed to be involved in these losses. However, more than a year after scientists began investigating this phenomenon, the factors causing CCD are still poorly understood (Benjamin and McCallum, 2008).

Despite the absence of evidence for CCD in Europe, contemporaneously beekeepers and researchers have had to face a new foreign invasion: honeybee microsporidia. While $N$. apis was described a century ago (Zander, 1909) as the causative agent for infections in A. mellifera, $N$. ceranae has more recently been found in the eastern honey bee, A. cerana (Fries et al., 1996). Recent studies demonstrate that both of them are able to infest (or co-infest) $A$. mellifera. $N$. ceranae has probably spread into A. mellifera populations within Europe very rapidly since 1998 (Paxton et al., 2007), suggesting that it is a pathogen with high transmission rates. Exhaustive research has led to the conclusion that $N$. ceranae infection could well be the cause of CCD (Higes et al., 2008).

Other introduction events have been recently described. Vespa velutina, the Asian hornet, was accidentally introduced into southern France (http://www.beedata.com/apis-uk/ index.htm). The "Small Hive Beetle" (SHB, Aethina tumida), native to sub-Saharan Africa (Dietemann et al., 2009) and also to Australia (B. Oldroyd, unpubl. data.), first detected in North America in 1998 in the state of Florida, was also detected at a Portuguese apiary in 2004, in spite of the European import embargo placed on colonies from countries with this parasite (Hood, 2004). Nowadays, due to intensive intercontinental trading, the risk and speed of spread of introduced exotic pests and pathogens is higher than 25 years ago. 


\subsection{Pesticides and herbicides}

The behavioural effects of bees following exposure to insecticides has been extensively reviewed by Thompson (2003); insecticide exposure leads to profound alterations in several biological aspects of honey bees such as division of labour, foraging behaviour, colony development and nestmate recognition. Lethal and sub-lethal effects on honeybees have been reported at or below the levels estimated for sprayed application in the field.

Systemic use of pesticides (some of them insecticides) is nowadays common, including coating seeds to preserve them before sowing. This technique causes persistence of the pesticide's active substances on the seed/growing plant and also in the soil, surrounding water and the environment at large. Among these compounds are Sevin dust (Active Substance A.S. - methylcarbamate), Gaucho 350FS (A.S. imidacloprid), Regent (A.S. fipronil), Cruiser 350FS (A.S. thiametoxam) and Poncho (A.S. clothianidin), all of them but fipronil belonging to the class of insecticides termed neonicotinoids, which are neurotoxic and highly soluble in water (Greatti et al., 2006). France has assessed damages following honeybee exposure to systemic insecticides (Rortais et al., 2005) and has strictly limited the use of these chemicals since the 1990s. The chemical company Bayer CropScience has offered to support German beekeeping over two million euros in 2008 for damage to honeybees caused by the insecticide Poncho Pro (Ministry of Food and Agriculture of Baden-Württemberg, 2008). Seed treatment with Poncho Pro has been consequently banned in Germany since May 2008 (Federal Office for Consumer Protection and Food Safety of Germany, 2008). However, research suggests that nectar from seed-treated plants does not affect honey bees (Schmuck et al., 2001; Bailey et al., 2005; Faucon et al., 2005). These conflicting conclusions suggest that most EU countries should distrust these chemicals at least until their influence on colony health is better understood. There might be synergistic effects between substances we poorly know, and sublethal effects from chemical insecticides may still impact colony productivity and winter survival. Finally, the impact of certain pathogens on honeybee colony vitality could also be influenced by an external chemical/insecticidal pressure.

\subsection{EU legislations and polices}

EU beekeeping legislation has not always been consistent regarding the preservation of honeybee biodiversity; the use of local races has been encouraged in the past (EU Regulation 1804/99) but honeybee trading without any race constraint or inspection is currently allowed if sanitary certificates are provided (Decision 2003/881/CE).

In addition, EU agronomic policies (Directive 2003/30/EC) promote bio-fuel production; by $2010,5.75 \%$ of Europe's transport fuel will be bio-fuel, increasing to $10 \%$ by the year 2020. This goal will profoundly change the current environmental scenario, enhancing deforestation and leading to a reduction of natural habitats and the substitution of crops with oil seed plants (potentially poor nectar producers). Large scale effects of these agricultural and land-use changes on beekeeping are still unknown.

Finally, the regulation of GMO plants is still controversial. A dozen GMOs have been allowed in the EU since 1990 (Directive 90/220/EEC), then non-GMO activists pushed public opinion to stop the introduction of new GMO cultivars between 1998 and 2004, and drove the enactment of new laws (Directive 2001/18/EC, Regulations 1829/2003/EC and $1830 / 2003 / E C)$ that better define and regulate GMO uses. Legislators could not rely on science to set up general rules, since available data suggested that transgenic plant impacts on pollinators are dependent on the situation and require a case-by-case analysis (Malone and Pham-Delègue, 2001). There are still outstanding issues. Are the GM traits really dangerous? Is GM pollen toxic to honeybee larvae? Do bees modify their foraging behaviour on GM crops? Although most studies do not show negative effects of GMOs on bee survival (particularly GMOs with the Bt gene) (Duan et al., 2008 and further references therein), it 
is necessary to carry out more detailed studies to assess the impact of GMOs on honeybee biology.

\section{FUTURE RESEARCH}

The recently available honeybee genome (The Honeybee Genome Sequencing Consortium, 2006) provided new molecular tools to analyze genetic, physiological and behavioural aspects of the honeybee (see also Zayed, 2009). One such tool is single-nucleotide polymorphisms (SNPs), which are DNA sequence variations occurring where a single nucleotide in the genome differs between at least $1 \%$ of the members of a group (i.e. population, subspecies or species). Over a million SNPs have been produced from pooled drones used as DNA sources (Robinson et al., 2006). A panel of 1136 SNPs (618 genome-derived and 520 EST-derived) has been used for characterizing the subspecies of $A$. mellifera and the Africanization process (Whitfield et al., 2006), and resulted in the confirmation of the hypothesis that the place of the origin of A. mellifera was in Africa, instead of previous hypotheses locating this origin in the Middle East (e.g., Garnery et al., 1992). Ancient and recent invasive expansions of $A$. mellifera are associated with a genome-wide signature of positive selection, as has been demonstrated by contrasting genetic differentiation estimates between coding and noncoding SNPs (Zayed and Whitfield, 2008). Both studies (Whitfield et al., 2006; Zayed and Whitfield, 2008) demonstrate the usefulness of the SNPs to elucidate classical problems of population genetics and highlight their potential for future studies.

Other broadly used molecular genetic markers are microsatellites, DNA motifs of one to six base pairs that are highly repeated, typically neutral, co-dominant and highly polymorphic (Box 3). As they are densely distributed over the whole genome, microsatellite loci can be used for mapping quantitative trait loci (QTL) (Lattorff et al., 2007). Identified QTLs could be extremely useful in future selective breeding programmes aiming at improving honey production, decreasing ag- gressiveness or enhancing disease resistance (Rüppell et al., 2004). Tightly linked microsatellite markers have also recently proven a powerful tool to estimate the relative density of colonies in a honeybee population (Moritz et al., 2007b). Accurate measurements of population density are essential for any meaningful assessment of honeybee decline (Paini, 2004). Shaibi et al. (2008) developed a toolkit for studying population structure in honeybees, consisting of sets of six tightly linked microsatellite loci in three different chromosomes. Considering the extremely high recombination rates found in A. mellifera (Beye et al., 2006), this series of independent linkage groups can reduce non-detection errors (the probability of obtaining two identical genotypes in two different individuals by chance) by more than five orders of magnitude in comparison with unlinked markers. Hence, this tool allows very accurate reconstruction of queen genotypes from random samples of honeybee drones and workers, and may even allow discrimination between the offspring of closely related laying sister workers in a colony. Furthermore, by choosing markers linked to genes which are under different modes of selection, additional information concerning natural and artificial selection in honeybee populations can be obtained (Shaibi et al., 2008).

Proteomics in A. mellifera has mainly focused on the analysis of the royal jelly (Schonleben et al., 2007; Li et al., 2007), seminal fluid (Baer et al., 2009) and venom composition (Peiren et al., 2005). A number of differences have been found between the protein complement of royal jelly of Italian and Carnica honeybees ( $\mathrm{Li}$ et al., 2007). An interesting approach is now open with the availability of the genome sequence through the possibility of identifying the expression products of coding genes.

\section{CONCLUSIONS}

A final reflection on all the issues treated above is that honeybee protection is tightly linked to the maintenance of beekeeping as a promising agricultural practice, attractive to 
young generations who may be rewarded with economic, social and personal benefits. Increasing professionalism, developing modern systems for colony exploitation, investing in scientific research on many aspects of bee biology, genetics, behavior or disease control, and implementing adequate polices for protecting valuable ecotypes are all actions that may help maintain beekeeping in the coming decades. Lessons from the recent past in the United States are unquestionable; European agriculture needs pollinators and most of them are to be maintained by a relatively unknown and not always well-appreciated figure, that of the beekeeper. Protection and conservation measures should never forget this entrepreneur.

\section{ACKNOWLEDGEMENTS}

We thank numerous research institutes and beekeeping organizations for providing national beekeeping statistics. Dr. Peter Neumann facilitated the contact information for many institutions, Dr. Hannes Kaatz mediated with German beekeeping organizations and Prof. Robin F. A. Moritz improved previous versions of this manuscript. Dr. Robert J. Paxton and Dr Peter Rosenkranz kindly help with the editing of this article. This project was supported by funding from the BEESHOP European network (FOOD-CT-2006-022568). Dr. Pilar De la Rúa and Irene Muñoz are funded by the Spanish Ministry of Science and Innovation.

\section{Box 1. Morphological analysis}

Morphological traits have been widely used in honeybee taxonomy long before molecular tools became available (Alpatov, 1929; Goetze 1940). Classical studies to differentiate honeybee subspecies based on morphological data have used multiple body characteristics, including worker body size, hair length, wing length and width, pigmentation, and proboscis length (Ruttner, 1988; Rinderer et al., 1993; Crewe et al., 1994; Ftayeh et al., 1994). Within the honeybee, Apis mellifera, morphological variation provided the basis for sub-specific classification following the exhaustive and extensive work of Ruttner (Ruttner, 1988, 1992; Ruttner et al., 1978) that, together with further studies (Sheppard, 1997; Sheppard and
Meixner, 2003), finally yielded the classification of 26 subspecies. Others have tried to apply this tool to distinguish between local ecotypes (Strange et al., 2007), but failed. Morphometry has also been used to detect changes in isolated populations (Floris and Prota, 1994). Honeybee biometric characters have also been investigated with the goal of detecting the range limits of a single subspecies (i.e. A. m. mellifera in Eastern Europe; Meixner et al., 2007), or to evaluate biometric variation within natural hybrid zones (i.e. for A. m. ligustica: Marletto el al., 1984a, b; Nazzi, 1992a, b; for A. m. iberiensis: Ruttner et al., 1978; Ruttner, 1988; Cornuet and Fresnaye, 1989; Orantes-Bermejo and GarcíaFernández, 1995; Hepburn and Radloff, 1996; Arias et al., 2006).

Despite the high variability in morphological traits that enhance the sensitivity of morphometric analysis, the first developed methods were time consuming. Thereafter, several attempts have been made to simplify morphological determination; computer assisted measurements (Daly et al., 1982; Batra, 1988; Schroder et al., 2002; Tofilski, 2004), reduced number of characters (Cermak and Kaspar, 2000; Dedej and Nazzi, 1994), and/or reduced number of bees (Francoy et al., 2006). Recently, two new inexpensive and fast, automated approaches (ABIS, Steinhage et al., 2001, 2007) and geometric morphometrics (Bookstein, 1991) have been successfully used to detect Africanization (Francoy et al., 2008). However, the situation in the Mediterranean basin and Europe is more complex, with many distinct subspecies of limited geographic ranges (Kauhausen-Keller et al., 1997). The efficiency of these new, fast methods has still to be confirmed within taxa widespread in the EU27 countries. If successful, this tool is likely to be used on a long-term basis, being suitable for researches and routine services for beekeepers.

\section{Box 2. Mitochondrial DNA analysis}

Mitochondrial DNA is maternally inherited and therefore provides information about the maternal ancestry of an entire colony just 
by analyzing one worker bee. Mitochondrial markers can be used to investigate the ancestry of individual colonies or the pattern of gene flow or introgression among hybridizing populations. The first studies on European honeybee biodiversity based on mitochondrial markers date back to 1986 (Moritz et al., 1986), in which restriction fragment length polymorphism (RFLP) of the whole mitochondrial genome were used to discriminate among three European honeybee races: A. m. caucasica, A. m. ligustica and A. m. carnica. A similar approach but with different restriction enzymes was used to assess introgression between these latter two subspecies (Meixner et al., 1993) and to determine the mitochondrial variation of endemic honeybee races across their natural range (Sheppard et al., 1996). Since the Africanization of feral honeybee populations in the Americas, mitochondrial studies were much improved with the aim of characterising co-inhabiting African and European populations. A different approach was then developed consisting of RFLPs of PCR-amplified fragments. Using this technique, several mitochondrial genes revealed discriminative power to distinguish between European or African derived honeybees (Hall and Smith, 1991) and the Old World honeybee subspecies. The most widely used mitochondrial region is the tRNAleu-cox 2 region (also named COI-COII) described by Cornuet and Garnery (1991). This intergenic region shows length and sequence variation related to honeybee evolutionary lineages. It is composed of two types of sequences: $\mathrm{P}$ and $\mathrm{Q}$. The sequence $\mathrm{P}$ can be absent (lineage $\mathrm{C}$ ) or present in four different forms: $\mathrm{P}$ (lineage $\mathrm{M}$ ), $\mathrm{P}_{0}$ (African lineage), $\mathrm{P}_{1}$ (African Atlantic sub-lineage, De la Rúa et al., 1998, 2001a, 2006) and $\mathrm{P}_{2}$ (restricted to a newly described $\mathrm{Y}$ lineage from Ethiopia, Franck et al., 2001). The number of $\mathrm{Q}$ sequences and the sequence variation developed through an RFLP test with the restriction enzyme DraI (Garnery et al., 1993) can be used to determine the haplotype within each lineage. Since this test was published, it has been extensively used to assess genetic diversity in native honeybee populations (Arias et al., 2006; Cánovas et al., 2008, Garnery et al., 1995, 1998a; Franck et al., 1998, 2000a, b, 2001; Jensen et al., 2005; De la Rúa et al., 1998, 2001a, b, 2002b, 2005, 2006; Miguel et al., 2007) and also to determine the origin of Africanized honeybee populations and the Africanization process on the American continent (Sheppard et al., 1999; Clarke et al., 2001; Abrahamovich et al., 2007).

\section{Box 3. Nuclear DNA analysis}

Biparentally inherited nuclear markers provide more powerful information about population events such as the introgressive hybridization through mating between drones and queens. Nuclear analyses of A. mellifera involved two different types of markers: allozymes and those that are DNA-based, such as nuclear RFLPs, RAPDs (Random amplified polymorphic DNA), AFLPs (Amplified fragment polymorphic DNA) and now widely used microsatellites. Only two of them have been extensively applied to European honeybee populations, allozymes and microsatellites, whereas the other markers have been used to compare European or African-derived bees on the American continent following the Africanization process in the New World.

Allozymes yielded very few polymorphic loci, and the studies employing them are mainly based on variation at two enzymes, malate deshidrogenase (Mdh) and hexokinasa (Hk), which must exhibit substantial allele frequency differences to allow discriminating among $A$. mellifera subspecies and populations. Honeybees from France (Cornuet et al., 1982, 1986), Italy (Badino et al., 1983; Sheppard and Berlocher, 1985; Comparini and Biasolo, 1991), Sicily (Badino et al., 1985), Norway (Sheppard and Berlocher, 1984), Turkey (Kandemir and Kence, 1995; Kandemir et al., 2000, 2005), Spain (Smith and Glenn, 1995; Arias et al., 2006), Albania (Dedej et al., 1996), Greece (Badino et al., 1988; Bouga et al., 2005a) and Bulgaria (Ivanova et al., 2007) have been analysed with this methodology. The allozymic information depicted from the Old World subspecies has been used to study gene flow between European-derived and African-derived honeybee populations in the New World, as 
reviewed in Sheppard and Smith (2000; see also Schneider et al., 2004).

The first microsatellite loci of A. mellifera were described in 1993 (Estoup et al., 1993) and since then they have been used in numerous studies addressing not only the population genetics of the genus Apis but also other biological aspects such as mating frequency (reviewed in Palmer and Oldroyd, 2000), the anarchy syndrome (Chaline et al., 2002) or the control of reproductive dominance (Lattorff et al., 2007). Currently around 550 microsatellite loci are available for $A$. mellifera (Solignac et al., 2003) and a thirdgeneration microsatellite-based linkage map of the honey bee has been developed and compared with the sequence-based physical map (Solignac et al., 2007). Microsatellites have shown adequate genetic variation to track changes in European honeybee populations over time. Numerous studies have been performed at the country level since the original description of variation in a set of seven microsatellite loci in honeybee subspecies of the three major evolutionary lineages (Estoup et al., 1995). Spanish honeybee populations are the most studied with these molecular markers (Franck et al., 1998; Garnery et al., 1998b; De la Rúa et al., 2002a; Miguel et al., 2007). Italian honeybees have also been intensively analysed due to the frequent exportation of A. m. ligustica queens (Franck et al., 2000a, Jensen et al., 2005; Dall'Olio et al., 2007). Other studies on microsatellite variation in honeybee populations from Slovenia (Sušnik et al., 2004), Cyprus (Kandemir et al., 2006) and Turkey (Bodur et al., 2007) demonstrate their usefulness to detect recent events such as introduction of foreign subspecies and ensuing introgressive hybridization.

\section{Biodiversité, conservation et menaces ac- tuelles pesant sur les abeilles domestiques européennes.}

Apis mellifera / sous-espèces / biogéographie / protection / Europe / apiculture

Zusammenfassung - Biodiversität, Naturschutz und aktuelle Bedrohungen der europäischen Honigbienen. Die Unterarten der Honigbienen wur- den sowohl mit morphologischen (Box 1) als auch mit molekulargenetischen (Box 2 und 3) Methoden untersucht. Die in Europa vorkommenden elf Unterarten (Abb. 1) werden in vier evolutiven $\mathrm{Ab}$ stammungslinien eingeteilt. In den entsprechenden Verbreitungsgebieten sind die dazugehörenden Unterarten unterschiedlichen Klima- und Habitatsbedingungen sowie anthropogenen Einflüssen ausgesetzt. Unser erstes Ziel ist es, die Biodiversität der europäischen Honigbienen zu beschreiben und die Strategien zum Schutz der Honigbienen in den einzelnen Ländern zusammenzufassen. Hybridisierungsprozesse wurden vor allem auf der iberischen, italienischen und der Balkan-Halbinsel festgestellt, wohingegen natürliche (aufgrund von Genfluss durch die Mehrfachpaarung der Königin) und durch imkerliche Aktivitäten ausgelöste (durch die Einfuhr von Honigbienen-Unterarten außerhalb ihres natürlichen Verbreitungsgebietes) genetische Introgression in Zentral- und Osteuropa sowie auf Mittelmeerinseln beobachtet wurden. Verschiedene Naturschutzprogramme wurden auf europäischen Inseln (Dänemark, Spanien) und seit kurzem auch in anderen europäischen Ländern (Frankreich, Norwegen, Slowenien und Österreich) etabliert. Für einen sinnvollen Honigbienenschutz muss aber der Status der imkerlich gehaltenen Honigbienenpopulation in den jeweiligen Ländern mit berücksichtigt werden. Daher müssen zunächst detaillierte Informationen zur Imkerei in den einzelnen Ländern gesammelt werden, bevor zukünftige Naturschutzprogramme entwickelt werden (Abb. 2 und Tab. I in „supplementary data"). Auf dieser Grundlage werden zwei Hauptansätze für zukünftige Naturschutzrichtlinien vorgeschlagen: Beschränkung der Einfuhr von ,überlegenen“ Unterarten in Gebiete, die bereits von nativen Honigbienenpopulationen besetzt sind sowie die Aufrechterhaltung der genetischen Diversität in natürlichen Honigbienenpopulationen. Immer mehr Faktoren wie veränderte Landnutzung, die Verbreitung von Krankheitserregern und Parasiten, der Einsatz von Pestiziden und Herbiziden (Tab. I) bedrohen die Honigbienen in Europa und gefährden damit auch die Funktion des Ökosystems durch eine unzureichende Bestäubung von Wild- und Kulturpflanzen.

Das vor kurzem aufgeschlüsselte HonigbienenGenom bietet nun aber neue Möglichkeiten, auf molekularer Ebene die Genetik, Physiologie und das Verhalten der Honigbienen zu untersuchen. Molekulare Marker wie SNPs (,,Single Nucleotide Polymorphisms") und Mikrosatelliten ermöglichen neue Einblicke in die Populationsstruktur der Honigbienen und die Analyse des HonigbienenProteoms wird uns zusätzlich Informationen über die Struktur, Funktion und Wechselwirkungen der von den jeweiligen Genen produzierten Proteine geben.

Eine abschließende Überlegung ist, dass der Honigbienenschutz eng mit der Aufrechterhaltung der Imkerei verbunden ist, die als zukunftsträchtiger 
Bestandteil der landwirtschaftlichen Praxis auch für die junge Generation attraktiv sein sollte. Für eine nachhaltige Unterstützung der Imkerei sollten die Berufsausbildung verbessert, moderne Betriebsweisen eingeführt, angewandte Forschung zur Bienenbiologie, Genetik und Krankheitsbekämpfung durchgeführt sowie sinnvolle Richtlinien zum Schutz wertvoller Ökosysteme umgesetzt werden.

\section{Apis mellifera / Unterarten / Biogeographie / Na- turschutz / Europa / Imkerei}

\section{REFERENCES}

Abrahamovich A.H., Atela O., De la Rúa P., Galián J. (2007) Assessment of the mitochondrial origin of honeybees from Argentina, J. Apic. Res. 46, 191194.

Adam B. (1983) In search of the best strains of bees, Dadant Sons, Hamilton Illinois.

Aizen M.A., Feinsinger P. (1994) Forest fragmentation, pollination, and plant reproduction in a Chaco dry forest, Argentina, Ecology 75, 330351.

Alpatov W.W. (1929) Biometrical studies on variation and races of the honeybee Apis mellifera L., Rev. Biol. 4, 1-57.

Arias M.C., Sheppard W.S. (1996) Molecular phylogenetics of honey bees subspecies (Apis mellifera L.), Mol. Phylogenet. Evol. 5, 557-566.

Arias M.C., Rinderer T.E., Sheppard W.S. (2006) Further characterization of honey bees from the Iberian Peninsula by allozyme, morphometric and mtDNA haplotype analyses, J. Apic. Res. 45, 188196.

Badino G., Celebrano G., Manino A. (1983) Population structure and Mdh-1 locus variation in Apis mellifera ligustica, J. Hered. 74, 443-446.

Badino G., Celebrano G., Manino A., Longo S. (1985) Enzyme polymorphism in the Sicilian honey bee, Experientia 41, 752-754.

Badino G., Celebrano G., Manino A., Ifantidis M.D. (1988) Allozyme variability in Greek honeybees (Apis mellifera L.), Apidologie 19, 377-386.

Baer B., Heazlewood J.L., Taylor N.L., Eubel H., Millar A.H. (2009) The seminal fluid proteome of the honeybee Apis mellifera, Proteomics. DOI: 10.1002/pmic. 200800708

Bailey J., Scott-Dupree C., Harris R., Tolman J., Harris B. (2005) Contact and oral toxicity to honey bees (Apis mellifera) of agents registered for use for sweet corn insect control in Ontario, Canada, Apidologie 36, 623-633.

Batley M., Hogendoorn K. (2009) Diversity and conservation status of native Australian bees, Apidologie 40, 347-354.
Batra S.T.W. (1988) Automatic image analysis for rapid identification of Africanized honey bees, in: Needham G.R. (Ed.), Africanized honey bees and bee mites. Ellis Horwood Series in Entomology and Acariology, Halsted Press, New York, pp. 260-263.

Baudry E., Solignac M., Garnery L., Gries M., Cornuet J.M., Koeniger N. (1998) Relatedness among honeybees (Apis mellifera) of a drone congregation area, Proc. R. Soc. Lond. B. 265, 2009-2014.

Benjamin A., McCallum B. (2008) A World Without Bees, Guardian Books, 208 p.

Beye M., Gattermeier I., Hasselmann M., Gempe T., Schioett M., Baines J.F., Schlipalius D., Mougel F., Emore C., Rueppell O., Sirviö A., GuzmánNovoa E., Hunt G., Solignac M., Page R.E. (2006) Exceptionally high levels of recombination across the honey bee genome, Genome Res. 16, 13391344

Biesmeijer J.C., Roberts S.P.M., Reemer M., Ohlemuller R., Edwards M., Peeters T., Schaffers A.P., Potts S.G., Kleukers R., Thomas C.D., Settele J., Kunin W.E. (2006) Parallel declines in pollinators and insect-pollinated plants in Britain and the Netherlands, Science 313, 351-354.

Bodur C., Kence M., Kence A. (2007) Genetic structure of honeybee, Apis mellifera L. (Hymenoptera: Apidae) populations of Turkey inferred from microsatellite analysis, J. Apic. Res. 46, 50-56.

Bookstein F.L. (1991) Morphometric Tools for Landmark Data, Geometry and Biology, Cambridge University Press.

Bouga M., Kilias G., Harizanis P.C., Papasotiropoulos V., Alahiotis S. (2005a) Allozyme Variability and Phylogenetic Relationships in Honey Bee (Hymenoptera: Apidae: Apis mellifera) populations from Greece and Cyprus, Biochem. Genet. $43,471-483$.

Bouga M., Harizanis P.C., Kilias G., Alahiotis S. (2005b) Genetic divergence and phylogenetic relationships of honeybee Apis mellifera (Hymenoptera: Apidae) populations from Greece and Cyprus using PCR-RFLP analysis of three mtDNA segments, Apidologie 36, 335-344.

Cánovas F., De la Rúa P., Serrano J., Galián J. (2008) Geographical patterns of mitochondrial DNA variation in Apis mellifera iberiensis (Hymenoptera: Apidae), J. Zool. Syst. Evol. Res. 46, 24-30.

Carreck N.L. (2008) Are honey bees (Apis mellifera L.) native to the British Isles? J. Apic. Res. 47, $318-322$.

Cermak K., Kaspar F. (2000) A method of classifying honey bee races by their body characters, Pszcz.. Zesz. Nauk. (XLIV) 2, 81-86.

Chaline N., Ratnieks F.L.W., Burke T. (2002) Anarchy in the UK: Detailed genetic analysis of worker reproduction in a naturally occurring British 
anarchistic honeybee, Apis mellifera, colony using DNA microsatellites, Mol. Ecol. 11, 1795-1803.

Clarke K.E., Rinderer T.E., Franck P., Quezada-Euan J.G., Oldroyd B.P. (2001) The Africanization of honeybees (Apis mellifera L.) of the Yucatan: A study of a massive hybridization event across time, Evolution 56, 1462-1474.

COAG (2007) Anuario Agrario: Apicultura, [online] http://194.30.12.92/rep_ficheros_web/ 208c4f87992370db4f614556778e04e7.pdf (accessed on 9 February 2009).

Comparini A., Biasiolo A. (1991) Genetic discrimination of Italian bee, Apis mellifera ligustica versus Carniolan bee, Apis mellifera carnica by allozyme variability analysis, Biochem. Syst. Ecol. 19, 189194.

Cornuet J.M., Fresnaye J. (1989) Étude biométrique de colonies d'abeilles d'Espagne et du Portugal, Apidologie 20, 93-101.

Cornuet J.M., Garnery L. (1991) Mitochondrial-DNA variability in honeybees and its phylogeographic implications, Apidologie 22, 627-642.

Cornuet J.M., Albisetti J., Mallet N., Fresnaye J. (1982) Étude biométrique d'une population d'abeilles landaises, Apidologie 13, 3-13.

Cornuet J. M., Daoudi A., Chevalet C. (1986) Genetic pollution and number of matings in a black honey bee (Apis mellifera mellifera) population, Theor. Appl. Genet. 73, 223-227.

Crewe R.M., Hepburn H.R., Moritz R.F.A. (1994) Morphometric analysis of 2 southern African races of honeybee, Apidologie 25, 61-70.

Dall'Olio R., Marino A., Lodesani M., Moritz R.F.A. (2007) Genetic characterization of Italian honeybees, Apis mellifera ligustica, based on microsatellite DNA polymorphisms, Apidologie 38, 207-217.

Daly H.V., Hoelmer K., Norman P., Allen T. (1982) Computer-assisted measurement and identification of honeybees (Hymenoptera: Apidae), Ann. Entomol. Soc. Am. 75, 591-594.

Dedej S., Biasiolo A., Piva R. (1996) Morphometric and alloenzyme characterization in the Albanian honeybee population Apis mellifera L., Apidologie 27, 121-131.

Dedej S., Nazzi F. (1994) Two distances of forewing venation as estimates of wing size, J. Apic. Res. 33, 59-61.

De la Rúa P., Serrano J., Galián J. (1998) Mitochondrial DNA variability in the Canary Islands honeybees (Apis mellifera L.), Mol. Ecol. 7, 1543-1547.

De la Rúa P., Galián J., Serrano J., Moritz R.F.A. (2001a) Genetic structure and distinctness of Apis mellifera L. populations from the Canary Islands, Mol. Ecol. 10, 1733-1742.
De la Rúa P., Galián J., Serrano J., Moritz R.F.A. (2001b) Molecular characterization and population structure of the honeybees from the Balearic islands (Spain), Apidologie 32, 417-427.

De la Rúa P., Galián J., Serrano J., Moritz R.F.A. (2002a) Microsatellite analysis of non-migratory colonies of Apis mellifera iberica from southeastern Spain, J. Zool. Evol. Res. 40, 164-168.

De la Rúa P., Serrano J., Galián J. (2002b) Biodiversity of Apis mellifera populations from Tenerife (Canary Islands) and hybridisation with East European races, Biodivers. Conserv. 11, 59-67.

De la Rúa P., Galián J., Serrano J., Moritz R.F.A. (2003) Genetic structure of Balearic honeybee populations based on microsatellite polymorphism, Genet. Sel. Evol. 35, 339-350.

De la Rúa P., Jimenez Y., Galián J., Serrano J. (2004) Evaluation of the biodiversity of honey bee (Apis mellifera) populations from eastern Spain, J. Apic. Res. 43, 162-166.

De la Rúa P., Hernandez-Garcia R., Jimenez Y., Galián J., Serrano J. (2005) Biodiversity of Apis mellifera iberica (Hymenoptera: Apidae) from northeastern Spain assessed by mitochondrial analysis, Insect Syst. Evol. 36, 21-28.

De la Rúa P., Galián J., Pedersen B.V., Serrano J. (2006) Molecular characterization and population structure of Apis mellifera from Madeira and the Azores, Apidologie 37, 699-708.

Dick C.W. (2001) Genetic rescue of remnant tropical trees by an alien pollinator, Proc. R. Soc. Lond. B 268, 2391-2396.

Dietemann V., Pirk C.W.W., Crewe R. (2009) Is there a need for conservation of Honeybees in Africa? Apidologie 40, 285-295.

Duan J.J., Marvier M., Huesing J., Dively G., Huang Z.Y. (2008) A meta-analysis of effects of Bt crops on honey bees (Hymenoptera: Apidae), PLoS ONE 3, e1415.

EC (2004) http://ec.europa.eu/agriculture/publi/ achievements/text_en.pdf.

EFSA (2008) Bee Mortality and Bee Surveillance in Europe, The Efsa J. 154, 1-28.

Estoup A., Solignac M., Harry M., Cornuet J.M. (1993) Characterization of (GT), and (CT) microsatellites in two insect species: Apis mellifera and Bombus terrestris, Nucleic Acids Res. 21, 1427-1431.

Estoup A., Garnery L., Solignac M., Cornuet J.M. (1995) Microsatellite variation in honey bee (Apis mellifera L.) populations: Hierarchical genetic structure and test of the infinite allele and stepwise mutation models, Genetics 140, 679-695.

EU (2004), Achievements in Agriculturall Policy under Commissioner Franz Fischler (Period 19952004). European Commission, Brussels, Belgium, pp. 1-31. 
Faucon J.P., Aurieres C., Drajnudel P., Mathieu L., Ribière M., Martel A.C., Zeggane S., Chauzat M.P., Aubert M.F.A. (2005) Experimental study on the toxicity of imidacloprid given in syrup to honey bee (Apis mellifera) colonies, Pest Manage. Sci. 61, 111-125.

Federal Office for Consumer Protection and Food Safety of Germany (2008) Hintergrundinformation: Bienenverlust durch insektizide Saatgutbehandlungsmittel in Deutschland 2008, [online] http://www.bvl. bund.de/nn_491652/DE/08_PresseInfothek/01_ Presse_und_Hintergrundinformationen/01_PI_ und_HGI/PSM/2008/Hintergrundinformation_ BienensterbenII.html (accessed on 13 February 2009).

Floris I., Prota R. (1994) Variazione di alcune caratteristiche morfometriche nella popolazione di Apis mellifera L. della Sardegna nell'ultimo ventennio, Apicoltura 9, 163-175.

Flynn D.F.B., Gogol-Prokurat M., Nogeire T., Molinari N., Trautman Richers B., Lin B.B., Simpson N., Mayfield M.M., DeClerck F. (2009) Loss of functional diversity under land use intensification across multiple taxa, Ecol. Lett. 1, 22-33.

Franck P., Garnery L., Solignac M., Cornuet J.M. (1998) The origin of west European subspecies of honeybees (Apis mellifera): New insights from microsatellite and mitochondrial data, Evolution 52, 1119-1134.

Franck P., Garnery L., Celebrano G., Solignac M., Cornuet J.M. (2000a) Hybrid origins of honeybees from Italy (Apis mellifera ligustica) and Sicily (A. m. sicula), Mol. Ecol. 9, 907-921.

Franck P., Garnery L., Solignac M., Cornuet J.M. (2000b) Molecular confirmation of a fourth lineage in honeybees from the Near East, Apidologie 31, 167-180.

Franck P., Garnery L., Loiseau A. (2001) Genetic diversity of the honeybee in Africa: microsatellite and mitochondrial data, Heredity 86, 420-430.

Francoy T.M., Prado P.P.R., Gonçalves L.S., Costa L.D., De Jong D. (2006) Morphometric differences in a single wing cell can discriminate Apis mellifera racial types, Apidologie 37, 91-97.

Francoy T.M., Wittmann D., Drauschke M., Muller S., Steinhage V., Bezerra-Laure M.A.F., De Jong D., Goncalves L.S. (2008) Identification of Africanized honey bees through wing morphometrics: two fast and efficient procedures, Apidologie $39,1-7$.

Freitas B.M., Imperatriz-Fonseca V.L., Medina L.M., Kleinert A.M.P., Galetto L., Nates-Parra G., Quezada-Euán J.J.G. (2009) Diversity, threats and conservation of bees in the Neotropics, Apidologie 40, 332-346.

Fries I., Feng F., da Silva A., Slemenda S.B., Pieniazek N.J. (1996) Nosema ceranae n. sp. (Microspora, Nosematidae), morphological and molecular char- acterization of a microsporidian parasite of the Asian honey bee Apis cerana (Hymenoptera, Apidae), Eur. J. Protistol. 32, 356-365.

Ftayeh A., Meixner M., Fuchs S. (1994) Morphometrical investigation in Syrian honeybees, Apidologie 25, 396-401.

Gallai N., Salles J.M., Settele J., Vaissière B.E. (2009) Economic valuation of the vulnerability of world agriculture confronted with pollinator decline, Ecol. Econ. 68, 810-821.

Garnery L., Cornuet J.-M., Solignac M. (1992). Evolutionary history of the honey bee Apis mellifera inferred from mitochondrial DNA analysis, Mol. Ecol. 1 145-154.

Garnery L., Solignac M., Celebrano G., Cornuet J.M. (1993) A simple test using restricted PCR-amplified mitochondrial-DNA to study the genetic-structure of Apis mellifera L., Experientia 49, 1016-1021.

Garnery L., Mosshine E.H., Oldroyd B.P., Cornuet J.M. (1995) Mitochondrial-DNA variation in Moroccan and Spanish honey-bee populations, Mol. Ecol. 4, 465-471.

Garnery L., Franck P., Baudry E., Vautrin D., Cornuet J.M., Solignac M. (1998a) Genetic diversity of the west European honey bee (Apis mellifera and A. m. iberica). I. Mitochondrial DNA, Genet. Sel. Evol. 30, 49-74.

Garnery L., Franck P., Baudry E. Vautrin D., Cornuet J.M., Solignac M. (1998b) Genetic biodiversity of the West European honeybee (Apis mellifera mellifera and Apis mellifera iberica). II. Microsatellite loci, Genet. Sel. Evol. 30, 49-74.

Goetze G. (1940) Die beste Biene, Liedlof Loth Michaelis, Leipzig.

Greatti M., Barbattini R., Stravisi A., Sabatini A.G., Rossi S. (2006) Presence of the a.i. imidacloprid on vegetation near corn fields sown with Gaucho ${ }^{\circledR}$ dressed seeds, Bull. Insectology 59, 99-103.

Hall H.G., Smith D.R. (1991) Distinguishing African and European honey bee matrilines using amplified mitochondrial DNA, Proc. Natl Acad. Sci. USA 88, 4548-4552.

Hepburn H.R., Radloff S.E. (1996) Morphometric and pheromonal analyses of Apis mellifera L. along a transect from the Sahara to the Pyrenees, Apidologie 27, 35-45.

Higes M., Martín-Hernández R., Botías C., Garrido Bailón E., González-Porto A.V., Barrios L., del Nozal M.J., Bernal J.L., Jiménez J.J., García Palencia P., Meana A., (2008) How natural infection by Nosema ceranae causes honeybee collapse, Environ. Microbiol. 10, 2659-2669.

Hood W.M. (2004) The Small Hive Beetle, Aethina tumida: A Review, Bee World 85, 51-59.

Huryn V.M.B. (1997) Ecological impacts of introduced honey bees, Q. Rev. Biol. 72, 275-297. 
Ivanova E.N., Staykova T.A., Bouga M. (2007) Allozyme variability in honey bee populations from some mountainous regions in the southwest of Bulgaria, J. Apic. Res. 46, 3-7.

Jaffè R., Dietemann V., Crewe R.M., Moritz R.F.A. (2009) Temporal variation in the genetic structure of a drone congregation area: An insight into the population dynamics of wild African honeybees (Apis mellifera scutellata), Mol. Ecol. 18, 15111522.

Jensen A.B., Pedersen B.V. (2005) Honeybee Conservation: a case story from Læs $\varnothing$ island, Denmark, in: Lodesani M., Costa C. (Eds.), Beekeeping and conserving biodiversity of honeybee. Sustainable bee breeding. Theoretial and practical guide. Northern Bee Books, Hebden Bridge, pp. 142-164.

Jensen A.B., Palmer K.A., Boomsma J.J., Pedersen B.V. (2005) Varying degrees of Apis mellifera ligustica introgression in protected populations of the black honeybee, Apis mellifera mellifera, in northwest Europe, Mol. Ecol. 14, 93-106.

Kandemir I., Kence A. (1995) Allozyme variability in a central Anatolian honeybee (Apis mellifera L.) population, Apidologie 26, 503-510.

Kandemir I., Kence M., Kence A. (2000) Genetic and morphometric variation in honeybee (Apis mellifera L.) populations of Turkey, Apidologie 31, 343-356.

Kandemir I., Kence M., Kence A. (2005) Morphometric and electrophoretic variation in different honeybee (Apis mellifera L.) populations, Turk. J. Vet. Anim. Sci. 29, 885-890.

Kandemir I., Meixner M.D., Ozkan A., Sheppard W.S. (2006) Genetic characterization of honey bee (Apis mellifera cypria) populations in northern Cyprus, Apidologie 37, 547-555.

Kauhausen-Keller D., Ruttner F., Keller R. (1997) Morphometric studies on the microtaxonomy of the species Apis mellifera L., Apidologie 28, 295307.

Kevan P.G., Phillips T.P. (2001) The economic impacts of pollinator declines: an approach to assessing the consequences, Conserv. Ecol. 5, 8.

Koeniger N., Koeniger G. (2000) Reproductive isolation among species of the genus Apis, Apidologie 31, 313-339.

Kozmus P., Jevrosima S., Stanimirovic Z., Stojic V., Kulisic Z., Meglic V. (2007) Analysis of mitochondrial DNA in honey bees (Apis mellifera) from Serbia, Acta Vet. Beograd 57, 465-476.

Kraus B., Page R.E. (1995) Effect of Varroa jacobsoni (Mesostigmata Varroidae) on feral Apis mellifera (Hymenoptera: Apidae) in California, Environ. Entomol. 24, 1473-1480.

Kremen C., Williams N.M., Thorp R.W. (2002) Crop pollination from native bees at risk from agricultural intensification, Proc. Natl Acad. Sci. USA 99, 16812-16816.
Lattorff H.M.G., Moritz R.F.A., Crewe R.M., Solignac M. (2007) Control of reproductive dominance by the thelytoky locus in honeybees, Biol. Lett. 3, 292-295.

Li J.K., Wang T., Zhang Z.H., Pan Y. (2007) Proteomic analysis of royal jelly from three strains of western honeybees (Apis mellifera), J. Agric. Food Chem. 55, 8411-8422.

Lodesani M., Costa C. (2003) Bee breeding and genetics in Europe, Bee World 84, 69-85.

Louveaux J., Albisetti M., Delangue M., Theurkauff M. (1966) Les modalités de l'adaptation des abeilles (Apis mellifica L.) au milieu naturel, Ann. Abeille 9, 323-350.

Malone L., Pham-Delègue M. (2001) Effects of transgene products on honey bees (Apis mellifera) and bumblebees (Bombus sp.), Apidologie 32, 287 304.

Marletto F., Manino A., Pedrini P. (1984a) Intergradazione fra sottospecie di Apis mellifera L. in Liguria, Apic. Mod. 75, 159-163.

Marletto F., Manino A., Balboni G. (1984b) Indagini biometriche su popolazioni di Apis mellifera L. delle Alpi occidentali, Apic. Mod. 75, 213-223.

Matheson A., Buchmann S.L., O’Toole C., Westrich P., Williams I.H. (1996) The conservation of bees, Academic Press, Harcourt Brace, London.

Meixner M.D., Sheppard W.S., Poklukar J. (1993) Asymmetrical distribution of a mitochondrialDNA polymorphism between two introgressing honey-bee subspecies, Apidologie 24, 147-153.

Meixner M.D., Worobik M., Wilde J., Fuchs S., Koeniger N. (2007) Apis mellifera mellifera in eastern Europe-morphometric variation and determination of its range limits, Apidologie 38, 191197.

Miguel I., Iriondo M., Garnery L., Sheppard W.S., Estonba A. (2007) Gene flow within the M evolutionary lineage of Apis mellifera: role of the Pyrenees, isolation by distance and post-glacial re-colonization routes in the western Europe, Apidologie 38, 141-155.

Ministry of Food and Agriculture of BadenWürttemberg (2008) Abschlussbericht Beizung and Bienenschäde, [online] http://www. mlr.baden-wuerttemberg.de/mlr/allgemein/ Abschlussbericht_Bienenschaeden.pdf (accessed on 13 February 2009).

Moritz R.F.A., Hawkins C.F., Crozier R.H., Mackinley A.G. (1986) A mitochondrial DNA polymorphism in honeybees (Apis mellifera), Experientia 42, 322-324.

Moritz R.F.A., Härtel S., Neumann P. (2005) Global invasions of the western honey bee (Apis mellifera) and the consequences for biodiversity, Ecoscience 12, 289-301.

Moritz R.F.A., Kraus F.B., Kryger P., Crewe R.M. (2007a) The size of wild honeybee populations (Apis mellifera) and its implications for the conservation of honeybees, J. Insect Conserv. 11, 391-397. 
Moritz R.F.A., Dietemann V., Crewe R.M. (2007b) Determining colony densities in wild honeybee populations (Apis mellifera) with linked microsatellite DNA markers, J. Insect Conserv. 12, 455-459.

Murray T.E., Kuhlmann M., Potts S.G. (2009). Conservation ecology of bees: populations, species and communities, Apidologie 40, 211236.

Nazzi F. (1992a) Morphometric analysis of honey bees from an area of racial hybridization in northeastern Italy, Apidologie 23, 89-96.

Nazzi F. (1992b) Fluctuating forewing characters in hybrid honey bees from north-eastern Italy, J. Apic. Res. 31, 27-31.

Neumann P., Moritz R.F.A., Van Praagh J.P. (1999a) Queen mating frequency in different types of honey bee mating apiaries, J. Apic. Res. 38, 1118.

Neumann P., Van Praagh J.P., Moritz R.F.A., Dustmann J.H. (1999b) Testing reliability of a potential island mating apiary using DNA microsatellites, Apidologie 30, 257-276.

Oldroyd B.P., Nanork P. (2009) Conservation of Asian honey bees, Apidologie 40, 296-312.

Orantes-Bermejo F.J., García-Fernández P. (1995) Morphological variability of Apis mellifera iberica in different apiaries of southern Spain, J. Apic. Res. 34, 23-30.

Paini D.R. (2004) Impact of the introduced honey bee (Apis mellifera) (Hymenoptera: Apidae) on native bees: A review, Austral. Ecol. 29, 399-407.

Palmer K.A., Oldroyd B.P. (2000) Evolution of multiple mating in the genus Apis, Apidologie 31, 235248.

Paxton R.J., Klee J., Korpela S., Fries I. (2007) Nosema ceranae has infected Apis mellifera in Europe since at least 1998 and may be more virulent than Nosema apis, Apidologie 38, 558-565.

Peiren N., Vanrobaeys F., de Graaf D.C., Devreese B., Beeumen J.V., Jacobs F.J. (2005) The protein composition of honeybee venom reconsidered by a proteomic approach, Biochim. Biophys. ActaProt. Prot. 1752, 1-5.

Radloff S.E., Hepburn H.R., Hepburn C., De la Rúa P. (2001) Morphometric affinities and population structure of honeybees of the Balearic Islands in the Mediterranean Sea, J. Apic. Res. 40, 97-103.

Randi E. (2008) Detecting hybridization between wild species and their domesticated relatives, Mol. Ecol. 17, 285-293.

Reusch H.B.H., Wood T.E. (2007) Molecular ecology of global change, Mol. Ecol. 16, 3973-3992.

Rinderer T.E., Oldroyd B.P., Sheppard, W.S. (1993) Africanized bees in the U.S., Sci. Am. 269, 5258.
Robinson G.E., Evans J.D., Maleszka R., Robertson H.M., Weaver D.B., Worley K., Gibbs R.A., Weinstock G.M. (2006) Sweetness and light: illuminating the honey bee genome, Insect Mol. Biol. $15,535-539$.

Rortais A., Arnold G., Halm M.-P., Touffet-Briens F. (2005) Modes of honeybees exposure to systemic insecticides: estimated amounts of contaminated pollen and nectar consumed by different categories of bees, Apidologie 36, 71-83.

Rüppell O., Pankiw T., Page R.E. (2004) Pleiotropy, Epistasis and New QTL: The Genetic Architecture of Honey Bee Foraging Behavior, J. Hered. 95, 481-491.

Ruttner F. (1988) Biogeography and Taxonomy of Honeybees, Springer Verlag, Berlin.

Ruttner F. (1992) Naturgeschichte der Honigbienen, Ehrenwirth, Munich.

Ruttner F., Tassencourt L., Louveaux J. (1978) Biometrical statistical analysis of the geographic variability of Apis mellifera L. I: Materials and methods, Apidologie 9, 363-382.

Schmuck R., Schoning R., Stork A., Schramel O. (2001) Risk posed to honeybees (Apis mellifera L. Hymenoptera) by an imidacloprid seed dressing of sunflowers, Pest Manage. Sci. 57, 225-238.

Schonleben S., Sickmann A., Mueller M.J., Reinders J. (2007) Proteome analysis of Apis mellifera royal jelly, Anal. Bioanal. Chem. 389, 1087-1093.

Schroder S., Wittmann D., Drescher W., Roth V., Steinhage V., Cremers A.B. (2002) The new key to bee: Automated identification by image analysis of wings, in: Kevan P., Imperatriz Fonseca V.L. (Eds.), Pollinating bees - the Conservation Link Between Agriculture and Nature, Ministry of Environment, Brasilia.

Schneider S.S., DeGrandi-Hoffman G., Smith D.R. (2004) The African honey bee: factors contributing to a successful biological invasion, Annu. Rev. Entomol. 49, 351-376.

Shaibi T., Lattorff H.M.G., Moritz, R.F.A. (2008) A microsatellite DNA toolkit for studying population structure in Apis mellifera, Mol. Ecol. Resources 8, 1034-1036.

Sheppard W.S. (1997) Subspecies of Apis mellifera, in: Morse R.A., Flottum K. (Eds.), Honey Bee Pests, Predators and Diseases, A.I. Root Co., Medina, OH, USA, pp. 519-533.

Sheppard W.S., Berlocher S.H. (1984) Enzyme polymorphisms in Apis mellifera mellifera from Norway, J. Apic. Res. 23, 64-69.

Sheppard W.S., Berlocher S.H. (1985) New allozyme variability in Italian honey bees, J. Hered. 76, 4548. 
Sheppard W.S., Meixner M. (2003) Apis mellifera pomonella, a new honey bee subspecies from Central Asia, Apidologie 34, 367-375.

Sheppard W.S., Smith D.R. (2000) Identification of African-Derived Bees in the Americas: A Survey of Methods, Ann. Entomol. Soc. Am. 93, 159176.

Sheppard W.S., Rinderer T.E., Meixner M.D., Yoo H.R., Stelzer J.A., Schiff N.M., Kamel S.M., Krell R. (1996) Hinfl variation in mitochondrial DNA of old world honey bee subspecies, J. Hered. 87, 35-40.

Sheppard W.S., Arias M.C., Grech A., Meixner M.D. (1997) Apis mellifera ruttneri, a new honey bee subspecies from Malta, Apidologie 28, 287-293.

Sheppard W.S., Rinderer T.E., Garnery L., Shimanuki H. (1999) Analysis of Africanized honey bee mitochondrial DNA reveals further diversity of origin, Genet. Mol. Biol. 22, 73-75.

Sinacori A., Rinderer T.E., Lancaster V., Sheppard W.S. (1998) A morphological and mitochondrial assessment of Apis mellifera from Palermo, Italy, Apidologie 29, 481-490.

Smith D.R., Glenn T.C. (1995) Allozyme polymorphisms in Spanish honeybees (Apis mellifera iberica), J. Hered. 86, 12-16.

Smith D.R., Crespi B.J., Bookstein F.L. (1997) Fluctuating asymmetry in the honey bee, Apis mellifera: effects of ploidy and hybridization, J. Evol. Biol. 10, 551-574.

Soland-Reckeweg G., Heckel G., Neumann P., Fluri P., Excoffier L. (2008) Gene flow in admixed populations and implications for the conservation of the Western honeybee, Apis mellifera, J. Insect Conserv., in press, DOI:10.1007/s10841008-9175-0.

Solignac M., Vautrin D., Loiseau A., Mougel F., Baudry E. (2003) Five hundred and fifty microsatellite markers for the study of the honeybee (Apis mellifera L.) genome, Mol. Ecol. Notes 3, 307-311.

Solignac M., Mougel F., Vautrin D., Monnerot M., Cornuet J.M. (2007) A third-generation microsatellite-based linkage map of the honey bee, Apis mellifera, and its comparison with the sequence-based physical map, Genome Biol. 8, R66, DOI:10.1186/gb-2007-8-4-r66.

Southwick E.E., Southwick L. (1992) Estimating the economic value of honey bees (Hymenoptera: Apidae) as agricultural pollinators in the United States, J. Econ. Entomol. 85, 621-633.

Steinhage V., Arbuckle T., Schröder S., Cremers A.B., Wittmann D. (2001) ABIS: Automated
Identification of Bee Species, BIOLOG. Workshop, German Programme on Biodiversity and Global Change, Status Report, pp. 194-195.

Steinhage V., Schröder S., Lampe K.H., Cremers A.B. (2007) Automated extraction and analysis of morphological features for species identification, in: MacLeod N. (Ed.), Automated Object Identification in Systematics: Theory, Approaches, and Applications, pp. 115-129.

Strange J.P., Garnery L., Sheppard W.S. (2007) Persistence of the Landes ecotype of Apis mellifera mellifera in southwest France: confirmation of a locally adaptive annual brood cycle trait, Apidologie 38, 259-267.

Strange J.P., Garnery L., Sheppard W.S. (2008) Morphological and molecular characterization of the Landes honey bee (Apis mellifera L.) ecotype for genetic conservation, J. Insect Conserv. 12, 527-537.

Sušnik S., Kozmus P., Poklukar J., Megli V. (2004) Molecular characterisation of indigenous Apis mellifera carnica in Slovenia, Apidologie 35, 623 636.

The Honeybee Genome Sequencing Consortium (2006) Insights into social insects from the genome of the honeybee Apis mellifera, Nature 443, 931-949.

Thompson H.M. (2003) Behavioural effects of pesticides in bees - Their potential for use in risk assessment, Ecotoxicology 12, 317-330.

Tofilski A. (2004) DrawWing, a program for numerical description of insect wings, J. Insect Sci. 4, 17-21.

van Engelsdorp D., Underwood R., Caron D., Hayes J. (2007) An estimate of managed colony losses in the winter of 2006-2007: a report commissioned by the apiary inspectors of America, Am. Bee J. 147, 599-603.

Whitfield C.W., Behura S.K., Berlocher S.H., Clark A.G., Johnston J.S., Sheppard W.S., Smith D.R., Suarez A.V., Weaver D., Tsutsui N.D. (2006) Thrice out of Africa: Ancient and recent expansions of the honey bee, Apis mellifera, Science 314, 642-645.

Zander E. (1909) Tierische Parasiten als Krankenheitserreger bei der Biene, Münch. Bienenztg. 31, 196-204.

Zayed A. (2009) Bee genetics and conservation, Apidologie 40, 237-262.

Zayed A., Whitfield W.C. (2008) A genome-wide signature of positive selection in ancient and recent invasive expansions of the honey bee Apis mellifera, Proc. Natl Acad. Sci. USA 105, 3421-3426. 